\title{
Covid-19 Maternal Mortality in Abu Dhabi and the Northern Emirates and a review of all described maternal mortalities
}

\author{
Ghalia Ashoor ${ }^{1}$, Juan Acuna ${ }^{2}$, Saleema Wani ${ }^{3}$, Tarek Ansari ${ }^{3}$, Sally El Deeb ${ }^{4}$, Jane Kelly ${ }^{3}$, \\ and Paul Bosio ${ }^{3}$ \\ ${ }^{1}$ Fetal Medicine Research Institute \\ ${ }^{2}$ Khalifa University of Science Technology and Research \\ ${ }^{3}$ Corniche Hospital \\ ${ }^{4}$ Sheikh Khalifa General Hospital
}

July 29, 2020

\begin{abstract}
The case fatality rate of Covid-19 in pregnancies published so far varies significantly. In our cohort of 515 women we had 3 maternal deaths due to three varying pathologies related to Covid-19. Our first case died due severe ARDS and a superimposed Pneumothorax, our second case the main cause of death was Septic shock and our third case developed Covid-19 encephalitis that resulted in brain death. There is currently only 10 maternal mortality cases described in detail in the literature. All our 3 cases were of South Asian origin, 2 of which had a BMI above 35.
\end{abstract}

Covid-19 Maternal Mortality in Abu Dhabi and the Northern Emirates and a review of all described maternal mortalities

Authors: Ghalia Ashoor-Almahri (Subspecialist in Maternal and Fetal Medicine) ${ }^{1,2}$, Juan Acuna (Chair of the Department of Epidemiology and Public Health) ${ }^{3}$, Saleema Wani (Consultant in Obstetrics and Gynaecology) ${ }^{1}$, Tarek Ansari (Consultant in Anaesthesia) ${ }^{1}$, Sally El Deeb (Consultant in Obstetrics and Gynaecology $)^{4}$, Jane Kelly (Head of Quality) ${ }^{1}$, Paul Bosio(Consultant in Obstetrics and Gynaecology) ${ }^{1}$

1 Corniche Hospital, SEHA Health services, Abu Dhabi, UAE

2 Harris Birthright Research Centre, Kings College Hospital, London, UK

3 Khalifa University, Abu Dhabi, UAE

4 Sheikh Khalifa General Hospital, Umm-Al-Quwain, UAE

Running title: A review of Covid-19 related Maternal Mortality

Corresponding author: Dr Ghalia Ashoor, Harris Birthright Research Centre, Kings College Hospital, London, SE5 9RS, email: ghalia@doctors.org.uk

Abstract

The case fatality rate of Covid-19 in pregnancies published so far varies significantly. In our cohort of 515 women we had 3 maternal deaths due to three varying pathologies related to Covid-19. Our first case died due severe ARDS and a superimposed Pneumothorax, our second case the main cause of death was Septic shock and our third case developed Covid-19 encephalitis that resulted in brain death. There is currently only 10 maternal mortality cases described in detail in the literature. All our 3 cases were of South Asian origin, 2 of which had a BMI above 35 . 


\section{Introduction}

The case fatality rate of Covid-19 in pregnancy varies based on the current published studies (UKOSS 2020, Lumbreras-Marquez et al 2020). The UK Obstetric Surveillance System (UKOSS 2020) is the largest cohort published to date of 427 pregnant women with a positive SARS-CoV 2 RT-PCR test. In that cohort, 40 women (9\%) required level 3 critical care, of those 31 needed delivery due to COVID-19 and 9 were still pregnant whilst four required extracorporeal membrane oxygenation. In this study, 5 women died (3 of which were postnatal women) giving a case fatality rate of $1.2 \%$ and a SARS-CoV 2 associated maternal mortality rate of 5.6: 100,000 maternities (UKOSS). Whilst The percentage of women needing critical care is slightly higher than what has been reported from China (Phua et al 2020), the mortality rate is lower, perhaps reflecting a lower threshold for admitting pregnant women to level 3 critical care. It is important to note that 30 women (10 antenatal and 20 postnatal) were still inpatients at the time of analyses (UKOSS). Further, whether the maternal deaths recorded were related to Covid-19 is also unclear in this interim report.

The first Covid-19 case maternal mortality reported in the UK (see Table 1: case 1), was of a 29 year old woman of Pakistani origin with multiple comorbidities including obesity, type 2 diabetes mellitus (T2DM), renal tubular acidosis, asthma, and vitamin D deficiency (Ahmed et al 2020). She also had a still born baby in her first pregnancy which may also reflect her poor background health status. Booking investigations revealed $\mathrm{HbA} 1 \mathrm{c}$ of $9.7 \%$ and a high albumin creatinine ratio, correlating with subsequent poor diabetes control on metformin and insulin and an ultrasound scan at 26 weeks showing a large for gestational age baby and polyhydramnios. She had over 20 hospital attendances with reduced fetal movements and she eventually was administered corticosteroids for fetal lung maturity. At 29 weeks' gestation she was admitted with a fever and had a normal chest x-ray, was treated with antibiotics and prophylactic low molecular weight heparin (LMWH) and discharged home. She re-attended a week later with severe breathlessness requiring 100\% oxygen and diabetes ketoacidosis. She had a caesarean section the following day under GA. The baby was SARS-CoV 2 negative. She improved immediately post-delivery and was extubated on day 3 of admission(?) and continued on intermittent CPAP. However, on day 7 of admission her respiratory function deteriorated and she complained of new onset blurred vision. A CTPA revealed a right lower lobar pulmonary embolism with extensive bilateral ground-glass and patchy solid consolidation consistent with Covid-19 pneumonia and a head CT revealed basilar artery thrombosis. Both her respiratory and neurological conditions rapidly deteriorated and care was withdrawn the following day. This case highlights the thrombotic complications of Covid-19 in pregnancy (Ahmed et al 2020).

In another large cohort of 308 pregnant women with Covid-19 disease reported from Mexico as of the $17^{\text {th }}$ of May, there were 7 maternal deaths (Lumbreras-Marquez et al 2020). This study reports a case fatality rate of $2.3 \%$ in pregnant women with Covid-19 disease. The demographics and clinical characteristics of those that survived was compared to those that died and this illustrated that those that suffered a maternal mortality were older, were more likely to be diabetic and obese and have other comorbidities. However, of the 7 maternal deaths only two received intensive care and only one was intubated, raising questions about the quality of maternal care provided to these women. The complications of Covid-19 in pregnancy and the exact causes of the maternal deaths were not described.

In another report from New York on 43 infected pregnant women who presented to hospital for obstetric and non-obstetric reasons, only 2 women needed ICU admission and both recovered (Breslin et al 2020). This cohort included women that were screened for the disease (33\% were asymptomatic) and therefore likely reflects less severe disease at presentation. A much larger case series of 462 pregnant women from New York confirmed to be Covid-19 positive by RT-PCR between the $1^{\text {st }}$ of March to the $6^{\text {th }}$ of May was recently published (Blitz et al 2020). The number of women that were classified as severe or critical was 70 (15\%) and $13(2.8 \%)$ women were admitted to intensive care due to acute hypoxia. Among this group, 2 died (see Table 1: Case 2 and 3) and 11 were discharged from hospital. Therefore, the case fatality rate in this cohort was $0.4 \%$, still much lower than the UK and Mexican data (Blitz et al 2020, Lumbreras-Marquez et al 2020, UKOSS 2020).

The maternal mortality due to Covid-19 in Iran was recently published from seven level three maternity 
hospitals over a 30 day period. The total number of infected pregnant women is not reported and therefore the case fatality rate is not known in this cohort of women (Hantoushzadeh et al 2020). They had 9 pregnant women with severe Covid-19 disease (defined by a positive SARS-CoV 2 RT-PCR nucleic acid testing with dyspnea, blood oxygen saturation $<93 \%$ on room air or partial pressure of arterial oxygen to fraction of inspired oxygen $<300$ and an available death certificate) and there were 7 mortalities among these (See Table 1: case 2-8). All Covid-19 pneumonia was treated with osteltamivir, hydroxycholorquine, lopinavir/ritonavir, and low molecular weight heparin prophylaxis. If any of the following clinical signs occurred, loss of consciousness, respiratory rate $>24$, blood pressure $<90 / 60 \mathrm{mmHg}$, multilobar lung infiltration on $\mathrm{CT}$ or chest $\mathrm{x}$-ray or hypoxemia $<90 \%$, then ribavirin was added to the treatment protocol. Steroid treatment was not recommended and all these patients were admitted before 8th of March except one case. Antibiotic administration was dependent on the attending physician's clinical judgement. The cause of death in all seven cases is described in table 1 with the timeline of deterioration and intubation. The seven women were all in the second and third trimesters of pregnancy. Two of the women had no comorbidities, one was obese, three were over the age of 35 years and one suffered from gestational diabetes in pregnancy but none of them had significant hypertension, cardiovascular disease, asthma or renal disease. The women died between 5 to 32 days from the initiation of symptoms. As for the two survivors reported with severe disease, one was still on a ventilator for 35 days at the time of reporting and the other recovered following extubation after 20 days.

We are reporting our Covid-19 related mortality cases at the largest maternity hospital in United Arab Emirates (UAE) providing tertiary referral services. Corniche Hospital has been instrumental in the care of pregnant women in the Emirate of Abu Dhabi during this pandemic. As the primary designated referral centre, minimal care was provided for Covid-19 positive pregnant women outside our facility elsewhere in the Emirate of Abu Dhabi (Abu Dhabi city, Western region and Al Ain). We also provide outreach services and consultation to hospitals in the Northern Emirates of UAE. The Covid-19 related mortalities in pregnancy occurred in May and June; two of these occurred in the Emirate of Abu Dhabi and one was a referral case from the Northern Emirates. These cases should include all the Covid-19 related mortalities in the UAE outside the emirate of Dubai.

UAE Case A:

A Filipino (see Table 1: case 11) primigravida in her late twenties at 27 weeks' gestation was referred to our Hospital from a private facility with a 1 week history of fever and a dry cough. She was otherwise fit and well with no relevant past medical history or recognized co-morbidities and a body mass index of 22 . She had been tested with her partner 3 days previously and the RT-PCR results were negative. On arrival she had a borderline temperature of 37.7 degrees after taking paracetamol at home. Her oxygen saturations were $97 \%$ in room air and her cardiovascular parameters were all stable. She was admitted to an isolation room but 3 hours later her oxygen saturations dropped to $92 \%$ in room air, with a respiratory rate (RR) of $25 / \mathrm{min}$, blood pressure (BP) 91/56 $\mathrm{mmHg}$ and a heart rate (HR) of 95 beats per minute. She was initially started on $5 \mathrm{l} / \mathrm{min}$ oxygen through a nasal cannula and commenced on piperacillin-tazobactam antibiotics, anti-viral (lopinavirritonavir), hydroxychhloroquine and prophylactic low molecular weight heparin (LMWH). Three hours later, her BP dropped to $82 / 47 \mathrm{mmHg}$ with a stable pulse rate of 99 beats per minute and oxygen saturations at $99 \%$ on the $5 \mathrm{~L} / \mathrm{min}$ nasal oxygen and RR of 20 breaths/min. She was given a fluid challenge and started on a higher treatment dose of LMWH twice a day. The chest x-ray illustrated mid and lower zone pulmonary consolidation and ground glass patchy opacification consistent with COVID-19 pneumonia. A few hours later her saturations continued to drop on oxygen to $90 \%$ and therefore she was started on $15 \mathrm{~L} / \mathrm{min}$ oxygen using a non-rebreathing mask whilst her BP remained stable at $99 / 59 \mathrm{mmHg}$. She was moved to HDU for continuous monitoring where she initially remained stable until she attempted to mobilise when she desaturated again to $84 \%$. Arterial blood gas (ABG) showed partial pressure of oxygen $(\mathrm{PaO} 2)$ of 66 , prompting her team to switch her to $20 \mathrm{~L} / \mathrm{min}$ high flow nasal cannula (HFNC). Her BP was recording borderline low and therefore she was given another fluid challenge which stabilised her readings. The oxygen delivery was increased to $30 \mathrm{~L} / \mathrm{min}$ HFNC and a repeat ABG showed a $\mathrm{PaO} 2$ of 67.5 and evidence of hyperventilation. Proning was discussed with her but she was unable to tolerate it as she was getting exhausted with increasing shortness of breath. She was therefore started on non-invasive ventilation (NIV) using BIPAP with a PEEP of 8 which 
improved her gasses significantly to a $\mathrm{PaO} 2$ of 172 . Since her ABG were normal, the Fio2 was gradually decreased from 0.95 to 0.7 over the subsequent 24 hours. Although her oxygen saturations were normal, repeat $\mathrm{ABG}$ showed a $\mathrm{PaO} 2$ of 83 and therefore the $\mathrm{FiO}_{2}$ (fraction of inspired oxygen) was again increased accordingly. She was stable and repeat arterial blood gasses (ABG) were normal until the morning of day 8 of admission (and day 7 of critical care) with a $\mathrm{PaO} 2$ of 65 on $\mathrm{BiPAP}$ (bilevel positive airway pressure) and $\mathrm{FiO}_{2}$ of $0.7 \%$. Throughout the day the $\mathrm{FiO}_{2}$ was gradually but repeatedly increased to increase her saturations but her $\mathrm{PaO} 2$ was still 66 and she was getting increasingly physically exhausted. She was therefore intubated that same evening and a central line inserted under ultrasound guidance. The patient remained unstable with little improvement in her $\mathrm{PaO} 2$ and was showing signs of haemodynamic instability when the decision to proceed with an emergency Caesarean section was made. This was performed bedside in the ICU and was surgically uneventful. Her oxygen saturation continued to drop and a bedside chest ultrasound showed a loss of the sliding sign and therefore a pneumothorax was suspected. Repeat chest x-ray confirmed a massive right-sided tension pneumothorax with right lung compression and mediastinal shift to the left in addition to severe progressive bilateral pulmonary consolidation. A chest drain was successfully inserted, and the central line was changed to a quad lumen catheter, but she continued to deteriorate despite full ventilation and inotropic support and arrested 2 times before resuscitation was stopped after 5 cycles of unsuccessful CPR (cardiopulmonary resuscitation) on the occasion of her third cardiac arrest in the early hours of the next morning.

\section{UAE Case B:}

A Nepalese woman (see Table 1: case 12) in her mid-thirties was admitted from the Emergency Department(ED) with severe ARDS on presentation. She was cyanotic on admission, with saturations of $30 \%$ and was very agitated. She was clearly pregnant and was booked for antenatal care at a private facility but no documentation on gestational age was available on presentation. Collateral history suggested she was approximately 26 weeks into her first pregnancy and had been symptomatic at home for 5 days prior to arriving in hospital. Although she had an elevated BMI of 36, she had no other reported co-morbidities. She was immediately intubated in the ED and started on antibiotics and prophylactic LMWH and transferred to the ICU. In the ICU she was also commenced on antivirals as well as hydroxycholorquine and needed norepinephrine to maintain a MAP above $>65$. A chest $\mathrm{x}$-ray demonstrated extensive patchy airspace opacity bilaterally in keeping with Covid-19 pneumonia. A bedside ultrasound indicated a likely gestational age of 26 weeks and a decision was made for delivery following multidisciplinary discussions in order to improve maternal resuscitation measures; intramuscular betamethasone was given for fetal lung maturity. On Day 2 following admission, an uncomplicated caesarean section was done bedside in ICU and a 800g baby boy was delivered in reasonable condition, intubated and transferred to NICU. During the Caesarean section, intra-operative oxygen saturations dropped to $78 \%$ and there was a mild drop in blood pressure for which she received $500 \mathrm{mls}$ of albumin. She was started on hydrocortisone and meropenem postoperatively and proning administered for 16 hours per day. Repeat nasopharyngeal RT-PCR taken after the antivirals were started was negative for Covid-19 but the patient continued to demonstrate clinical and radiological signs consistent with active progressive Covid-19 infection. On Day 3 post-Caesarean Section the dose of LMWH was increased to a therapeutic dose and the following day a repeat chest x-ray showed a mild improvement of the previously noted bilateral pulmonary ground glass opacification with no evidence of pleural effusion or pneumothorax. On Day 5 she was clinically stable, afebrile and inflammatory markers had all improved; all the culture results were negative and therefore the 7 day course of antibiotics and steroids were stopped. However the next day she suddenly deteriorated rapidly over the space of one hour with a temperature of 40 degrees, tachycardia and a gradual but sustained drop in blood pressure that was unresponsive to norepinephrine. She developed deep ST depression in association with worsening hypotension which was then followed by a ventricular escape rhythm with progressive bradycardia and then asystole. The cause of death was likely overwhelming septic shock.

\section{UAE Case C}

A Filipino lady in her late thirties (see Table 1: case 13) who presented at 22 weeks and has been symptomatic 
for 5 days with a fever, cough, runny nose sore throat and shortness of breath. She is para 3 and had three previous caesarean sections and her risk factors are a BMI of 39 and not receiving any antenatal care during this index pregnancy. On admission her RR was $28 / \mathrm{min}$, oxygen saturation was $93 \%$, BP 130/85 and a HR of 105 beats/min and an oxygen mask with $2 \mathrm{~L} / \mathrm{min}$ was needed to maintain her oxygen saturations at 97\%. She was swabbed for COVID-19 the day prior to admission and the result was positive on admission. Her chest x-ray demonstrated patchy opacification involving both lung fields. She was started on antibiotics and LMWH on the same day. She deteriorated a few hours later and required increase in oxygen flow to $7 \mathrm{~L} / \mathrm{min}$ to maintain the saturations of $95 \%$ and her respiratory rate was stable at 28 . The next day she developed metabolic acidosis likely secondary to diabetes with a serum bicarbonate of 11 and ketonuria, her previous history of gestational diabetes puts her at high risk of pre-existing undiagnosed diabetes mellitus for which she was treated. In addition, she also required increasing oxygen demand, and was started on HFNC and was treated with another broad spectrum antibiotic, an IL-6 inhibitor, low dose methylprednisolone and the dose of LMWH was increased to therapeutic dose. The same day further hypoxia resulted in the patient being intubated and mechanically ventilated. A bedside scan showed a singleton pregnancy with an EFW corresponding to 24 weeks of gestation and normal amniotic fluid volume. She remained stable on $\mathrm{FiO} 2$ of $40 \%$ but continued to spike fevers so Tazobactam-piperacillin was changed to Merpenum. Her respiratory condition continued to improve and sedation was tapered down on day 10 of admission, however she was unresponsive and sluggish pupillary reflexes were noted. An MRI brain was performed which showed diffuse brain oedema with inferior brain herniation likely secondary to COVID-19 related encephalitis. Therefore dehydration measures were started and a CT brain a few days later was suggestive of global hypoxic injury with impending conisation. A neurological review demonstrated absent pupillary response, absent corneal reflex, no response to deep painful stimuli, spontaneous triggered responsiveness likely due to sparing of lower brain stem. A multidisciplinary team concluded that maternal outcome is poor due to irreversible neurological insult, and since the mothers cardiovascular condition is stable delivery will be delayed until a fetal ultrasound reassessment is performed at 28 weeks gestation and steroids for fetal lung maturity administrated. However in the case of maternal cardiorespiratory deterioration then delivery would be expedited. She started to spike temperatures again nearly 3 weeks after admission and blood, urine and sputum cultures all grew Candida Auris and she was started on antifungal treatment. A repeat fetal ultrasound scan showed a normally growing fetus with an EFW of $1.15 \mathrm{~kg}$ and since the temperature spikes continued with increasing frequency and severity a decision was made to expedite delivery to avoid fetal compromise and she had an upper segment caesarean section and cord gasses were normal. The placental histology was examined and there was no evidence of an inflammatory process and a swab from the placenta showed no growth on culture. A repeat CT brain 5 weeks after admission showed more progressive ischemic changes of the cerebellar hemispheres. Using the brain death policy issued by the UAE government, brain death determined by neurological criteria is equivalent to the death of the individual even though the heart continues to beat and spinal cord function may persist.

\section{Discussion}

The total number of pregnant women with COVID-19 disease identified in Abu Dhabi so far is 515 (unpublished data) and therefore our case fatality rate in Abu Dhabi is $0.5 \%$ lower than what has previously been published (UKOSS 2020, Lumbreras-Marquez et al 2020). All 10 mortalities described due to COVID-19 disease that have been published so far have occurred during the $2^{\text {nd }}$ or $3^{\text {rd }}$ trimester of pregnancy and our three cases also occurred in the second half of pregnancy (see Table 1). This is consistent with the 2009 H1N1 influenza pandemic (Siston et al 2010), where only 7\% of the maternal deaths occurred in the first trimester and $27 \%$ occurred in the second and the vast majority $(64 \%)$ occurred in the third trimester. The most common comorbidity in these women is the raised BMI ( 5 of the 13 women had a BMI $>35$ ), being of South Asian origin ( 4 of the 13 cases), advanced maternal age in 3 women and T2DM in 2 women.

The cause of death in our case series varied significantly indicating the wide range of COVID-19 related pathology, the first case was due to ARDS and a superimposed pneumothorax, the second case was overwhelming sepsis and the third case was secondary to encephalitis. The maternal death occurred between 5 to 32 days from symptom onset and between 2 to 22 days from admission date (see Table 1). Overall, cause 
of death was secondary to ARDS in 10 of 13 cases (77\%) and a pneumothorax complicated this in 3 of the 13 cases $(23 \%)$ which is therefore a likely adverse outcome of the lung disease due to COVID-19 and patients should be closely monitored for such complications. One patient suffered from both a pulmonary embolus as well as an ischemic stroke and was on LMWH from day 1 of symptoms however this patient has multiple comorbidities (see Table 1: case 1) which also highlights the thrombotic complications of COVID-19 disease in addition to the background increased risk of pregnancy and emphasises the need to start high treatment dose as soon as patient is admitted. Of course in cases where the delivery of the baby may be indicated then unfractionated heparin can be used for easier drug reversal. It is important to note that the $3^{\text {rd }}$ case is still on respiratory support and patient remains hospitalised at the time of this publication. Sepsis and septic shock contributed to the cause of death in 3 cases and in our second case (see Table 1: case 12) was the main cause as she deteriorated very quickly after the cessation of antibiotics after 9 days of administration even though clinically she was stable with improving inflammatory markers.

The rate of deterioration was rapid in all three cases in UAE from the point of admission to NIV or intubation indicating that patients were likely to have delayed hospital attendance until symptoms worsened which may also indicate that overall adverse outcome of other non-COVID-19 related pregnancy complications is likely to have increased during this pandemic and this needs further investigations. The majority have started antibiotics and antivirals as well as a LMWH on date of admission. However the treatment protocol differs in different units due to evolving knowledge and experience of the disease and there is a need for a more standardised evidence based approach as more evidence becomes available. The data published from the RECOVERY trial on the significant reduction in mortality in patients that need oxygen therapy is encouraging and should be taken into account when treating COVID-19 pregnant patients however data on pregnancy specific outcomes is still awaiting (Horby et al. 2020).

\section{Disclosure of Interest: Nil}

Contribution of authorship: GAA was in charge of the concept and did the initial writing of the manuscript. The manuscript was edited by PB, JA, TA, SW. JK and SD was in charge of data collection.

Ethical approval: Ethical approval was granted for this study by the Abu Dhabi Covid-19 Research IRB Committee. Consent was obtained from the next of Kin of the 3 cases of Maternal mortality for the publication of this manuscript.

Funding: No funding was received or requested.

\section{References:}

Ahmed I, Azhar A, Eltaweel N, Tan BK. First COVID-19 maternal mortality in the UK associated with thrombotic complications. Br J Haematol. 2020 May 18:10.1111/bjh.16849. doi: 10.1111/bjh.16849.

Blitz MJ, Rochelson B, Minkoff H, Meirowitz N, Prasannan L, London V, Rafael TJ, Chakravarthy S, Bracero LA, Wasden SW, Pachtman Shetty SL, Santandreu O, Chervenak FA, Schwartz BM, Nimaroff M. Maternal Mortality Among Women with COVID-19 Admitted to the Intensive Care Unit. Am J Obstet Gynecol. 2020 Jun 15:S0002-9378(20)30636-0.

Hantoushzadeh S, Shamshirsaz AA, Aleyasin A, Seferovic MD, Aski SK, Arian SE, Pooransari P, Ghotbizadeh F, Aalipour S, Soleimani Z, Naemi M, Molaei B, Ahangari R, Salehi M, Oskoei AD, Pirozan P, Darkhaneh RF, Laki MG, Farani AK, Atrak S, Miri MM, Kouchek M, Shojaei S, Hadavand F, Keikha F, Hosseini MS, Borna S, Ariana S, Shariat M, Fatemi A, Nouri B, Nekooghadam SM, Aagaard K. Maternal death due to COVID-19. Am J Obstet Gynecol. 2020 Apr 28:S0002-9378(20)30516-0. doi: 10.1016/j.ajog.2020.04.030.

Horby PW, Landray MJ. Effect of dexamethasone in hospitalized patients with COVID-19 - preliminary report. 22 Jun 2020 (preprint). https://www.medrxiv.org/content/10.1101/2020.06.22.20137273v1.full.pdf

Lumbreras-Marquez MI, Campos-Zamora M, Lizaola-Diaz de Leon H, Farber MK. Maternal mortality from COVID-19 in Mexico. Int J Gynaecol Obstet. 2020 May 30. doi: 10.1002/ijgo.13250. 
Marian Knight, Kathryn Bunch, Nicola Vousden, Eddie Morris, Nigel Simpson, Chris Gale, Patrick O'Brien, Maria Quigley, Peter Brocklehurst, Jennifer J Kurinczuk. Characteristics and outcomes of pregnant women hospitalised with confirmed SARS-CoV-2 infection in the UK: a national cohort study using the UK Obstetric Surveillance System (UKOSS) The UK Obstetric Surveillance System SARS-CoV-2 Infection in Pregnancy Collaborative Group

Phua J, Weng L, Ling L, et al. Intensive care management of coronavirus disease 2019 (COVID-19): challenges and recommendations. Lancet Respr Med 2020

Siston AM, Rasmussen SA, Honein MA, Fry AM, Seib K, Callaghan WM, Louie J, Doyle TJ, Crockett M, Lynfield R, Moore Z, Wiedeman C, Anand M, Tabony L, Nielsen CF, Waller K, Page S, Thompson JM, Avery C, Springs CB, Jones T, Williams JL, Newsome K, Finelli L, Jamieson DJ; Pandemic H1N1 Influenza in Pregnancy Working Group. Pandemic 2009 influenza A(H1N1) virus illness among pregnant women in the United States. JAMA. 2010 Apr 21;303(15):1517-25. doi: 10.1001/jama.2010.479.

Vallejo V, Ilagan JG. A Postpartum Death Due to Coronavirus Disease 2019 (COVID-19) in the United States. Obstet Gynecol. 2020 May 8. doi: 10.1097/AOG.0000000000003950.

Table 1: Clinical overview of the $\mathrm{x}$ maternal mortality cases published to date. Days documented are relative to the intial onset of COVID-19 symptoms except when * then these are days from point of admission as days of symptom onset prior to admission is unknown

**Patient is diagnosed brain dead however life support machine not yet switched off

Abbreviations: UN (unknown), PE (pulmonary embolus), ARDS (acute respiratory distress syndrome), OSA (obstructive sleep apnea), NA (not applicable), BMI (body mass index), T2DM (type 2 diabetes mellitus)

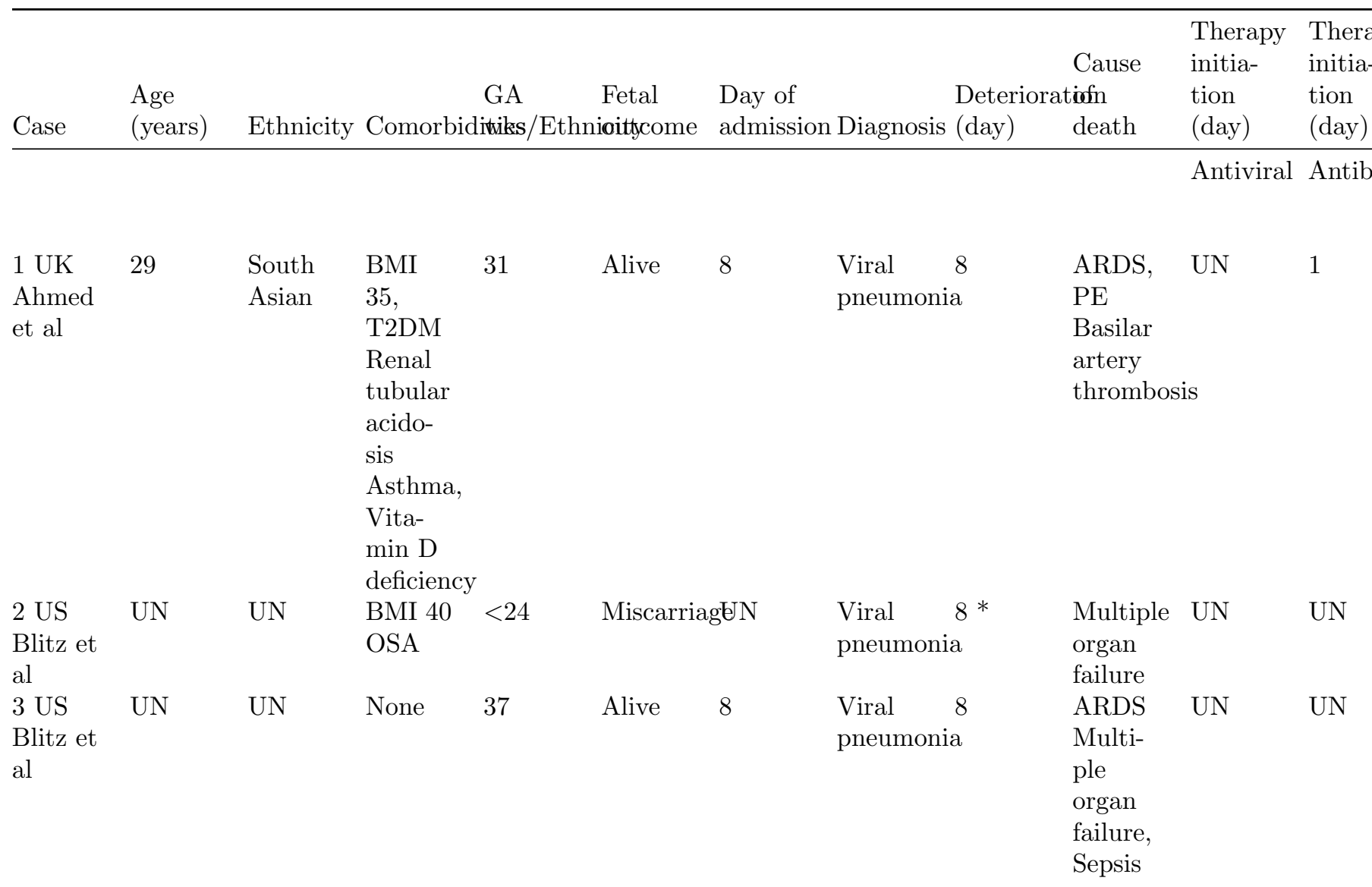




\begin{tabular}{|c|c|c|c|c|c|c|c|c|c|c|c|}
\hline Case & $\begin{array}{l}\text { Age } \\
\text { (years) }\end{array}$ & Ethnicity & Comorbid & $\begin{array}{c}\text { GA } \\
\text { ditiks /E }\end{array}$ & $\begin{array}{c}\text { Fetal } \\
\text { Ethniøittycome }\end{array}$ & $\begin{array}{l}\text { Day of } \\
\text { admission }\end{array}$ & Diagnosis & $\begin{array}{l}\text { Deteriora } \\
\text { (day) }\end{array}$ & $\begin{array}{l}\text { Cause } \\
\text { toofn } \\
\text { death }\end{array}$ & $\begin{array}{l}\text { Therapy } \\
\text { initia- } \\
\text { tion } \\
\text { (day) }\end{array}$ & $\begin{array}{l}\text { Therapy } \\
\text { initia- } \\
\text { tion } \\
\text { (day) }\end{array}$ \\
\hline $\begin{array}{l}\text { Iran } \\
\text { Han- } \\
\text { toushzaeh } \\
\text { et al }\end{array}$ & $25-29$ & Persian & None & 30 & Stillbirth & 4 & $\begin{array}{l}\text { Viral } \\
\text { pneumoni }\end{array}$ & $\begin{array}{l}5 \\
\text { ia }\end{array}$ & ARDS & 4 & 4 \\
\hline $\begin{array}{l}5 \text { Iran } \\
\text { Han- } \\
\text { toushzaeh } \\
\text { et al }\end{array}$ & $25-29$ & Persian & $\begin{array}{l}\mathrm{Bmi} \\
>35\end{array}$ & 38 & Alive & 2 & $\begin{array}{l}\text { Viral } \\
\text { pneumoni }\end{array}$ & $\begin{array}{l}4 \\
\text { ia }\end{array}$ & ARDS & 2 & 2 \\
\hline $\begin{array}{l}6 \text { Iran } \\
\text { Han- } \\
\text { toushzaeh } \\
\text { et al }\end{array}$ & 40-44 & Persian & $\begin{array}{l}\text { Advanced } \\
\text { mater- } \\
\text { nal age } \\
\text { Sub- } \\
\text { clinical } \\
\text { hypothyrc }\end{array}$ & $\begin{array}{l}\text { d } 30 \\
\text { oidsim }\end{array}$ & Alive & 7 & $\begin{array}{l}\text { Viral } \\
\text { pneumoni }\end{array}$ & $\begin{array}{l}10 \\
\mathrm{ia}\end{array}$ & ARDS & 11 & 11 \\
\hline $\begin{array}{l}7 \text { Iran } \\
\text { Han- } \\
\text { toushzaeh } \\
\text { et al }\end{array}$ & 30-34 & Persian & None & 24 & Stillbirth & 4 & $\begin{array}{l}\text { Viral } \\
\text { pneumoni }\end{array}$ & $\begin{array}{r}7 \\
\text { ia }\end{array}$ & $\begin{array}{l}\text { ARDS } \\
\text { Pneumotl }\end{array}$ & $\begin{array}{l}4 \\
\text { horax }\end{array}$ & 4 \\
\hline $\begin{array}{l}8 \text { Iran } \\
\text { Han- } \\
\text { toushzaeh } \\
\text { et al }\end{array}$ & 30-34 & Persian & $\begin{array}{l}\text { Gestation } \\
\text { diabetes }\end{array}$ & & Alive & 2 & $\begin{array}{l}\text { Viral } \\
\text { pneumoni }\end{array}$ & $\begin{array}{c}3 \\
\text { ia }\end{array}$ & $\begin{array}{l}\text { ARDS } \\
\text { Pneumot] }\end{array}$ & $\begin{array}{l}4 \\
\text { horax }\end{array}$ & 4 \\
\hline $\begin{array}{l}9 \text { Iran } \\
\text { Han- } \\
\text { toushzaeh } \\
\text { et al }\end{array}$ & 35-39 & Persian & $\begin{array}{l}\text { Advanced } \\
\text { mater- } \\
\text { nal } \\
\text { age }\end{array}$ & & $\begin{array}{l}\text { Twins } \\
\text { both } \\
\text { stillborn }\end{array}$ & 3 & $\begin{array}{l}\text { Viral } \\
\text { pneumoni }\end{array}$ & $\begin{array}{r}6 \\
\text { ia }\end{array}$ & $\begin{array}{l}\text { ARDS } \\
\text { Septic } \\
\text { shock } \\
\text { DIC } \\
\text { Heart } \\
\text { failure }\end{array}$ & 4 & 5 \\
\hline $\begin{array}{l}10 \text { Iran } \\
\text { Han- } \\
\text { toushzaeh } \\
\text { et al }\end{array}$ & 45-49 & Persian & $\begin{array}{l}\text { Advanced } \\
\text { mater- } \\
\text { nal age } \\
\text { BMI }<20\end{array}$ & & $\begin{array}{l}\text { Twins } \\
\text { both } \\
\text { alive }\end{array}$ & 14 & $\begin{array}{l}\text { Viral } \\
\text { pneumoni }\end{array}$ & $\begin{array}{l}15 \\
\text { ia }\end{array}$ & ARDS & 14 & 14 \\
\hline $\begin{array}{l}11 \\
\text { UAE }\end{array}$ & 28 & $\begin{array}{l}\text { South } \\
\text { Asian }\end{array}$ & None & 27 & Alive & 3 & $\begin{array}{l}\text { Viral } \\
\text { pneumoni }\end{array}$ & $\begin{array}{l}10 \\
\text { ia }\end{array}$ & $\begin{array}{l}\text { ARDS } \\
\text { Pneumotl }\end{array}$ & $\begin{array}{l}3 \\
\text { horax }\end{array}$ & 3 \\
\hline $\begin{array}{l}12 \\
\mathrm{UAE}\end{array}$ & 36 & $\begin{array}{l}\text { South } \\
\text { Asian }\end{array}$ & BMI 36 & 26 & Alive & 6 & $\begin{array}{l}\text { ARDS, } \\
\text { Septic } \\
\text { shock }\end{array}$ & 15 & $\begin{array}{l}\text { Septic } \\
\text { Shock }\end{array}$ & 6 & 6 \\
\hline $\begin{array}{l}13 \\
\text { UAE }\end{array}$ & 39 & $\begin{array}{l}\text { South } \\
\text { Asian }\end{array}$ & $\begin{array}{l}\text { BMI } 39 \\
\text { T2DM }\end{array}$ & 22 & Alive & 6 & $\begin{array}{l}\text { Viral } \\
\text { pneumoni }\end{array}$ & $\begin{array}{l}8 \\
\text { ia }\end{array}$ & Encephal & ittis & 6 \\
\hline
\end{tabular}

